\title{
Nulltimen - poeten Dorothy Parker og søvnløshet
}

\author{
Dorothy Parker (1893-1967) var ame- \\ rikansk poet og forfatter, kjent for \\ sine ondsinnede vittigheter, såre vers \\ og skarpe blikk for svakhetene hos \\ moderne urbane mennesker. Hun \\ skriver om sin søvnløshet og om den \\ tiden på døgnet der fortvilelsen er \\ størst og selvfølelsen minst.
}

Sigmund Freud (1856-1939) skrev 600 sider om å drømme, mens søvnløsheten ikke fikk så mye mer enn fotnoter. Søvnløsheten er desto grundigere tematisert i skjønnlitteraturen. Det litterære fellesskapet av rødøyde og slitne forfattere er påfallende stort. Charles Dickens (1812-70) var våken i London, Marcel Proust (1871-1922) i Paris, Franz Kafka (1883-1924) hadde håpløse netter i Praha, Fernando Pessoa (1888-1935) vandret og drakk i Lisboa, og Hjalmar Söderbergs (1869-1941) romanskikkelse doktor Glas driver omkring i Stockholm: «Varför får jag inte sova? Jag har inte begått något brott.»

Dorothy Parker skrev om å ligge søvnløs $i$ en seng i New York. Ved siden av sine kvikkheter, sarte vers og bittersøte fortel-

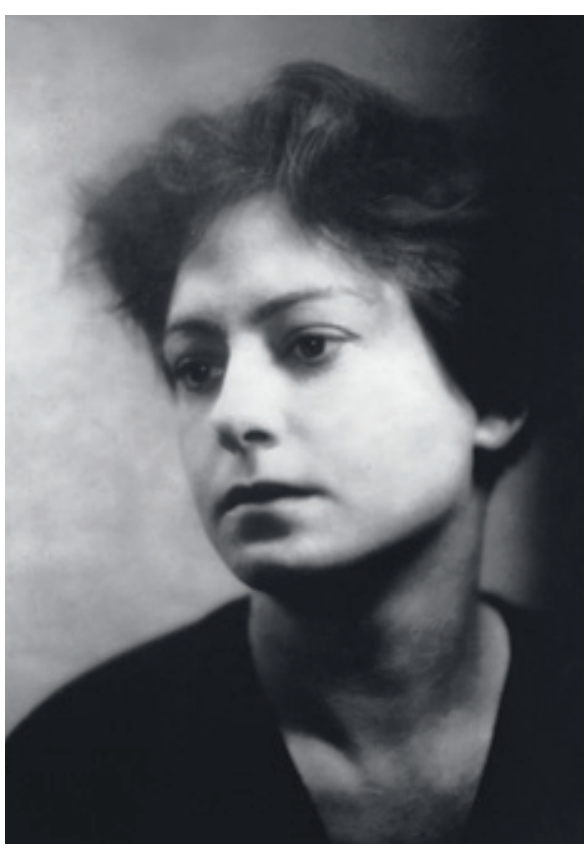

Dorothy Parker, tatt i 1920-årene. Foto (C) Bettmann/Corbis/SCANPIX linger var hun også en fryktet kritiker, spaltist og etter hvert også manuskriptforfatter i Hollywood. I flere år bodde hun på hotellet Algonquin, der hun var dronning for et hoff av intellektuelle newyorkere som kalte seg Algonquin Round Table. Utad fremsto hun som en sofistikert urban intellektuell, mens hun privat var selvdestruktiv. Hun hadde kompliserte relasjoner til sine ektemenn, var viklet inn i en rekke erotiske affærer, var fordrukken og gjorde flere selvmordsforsøk (1).

I teksten The little hours fra 1933 skriver hun både vittig og fortvilt, og ikke minst gjenkjennelig, om å være søvnløs (2) (Utdragene fra teksten er mine egne oversettelser). Klokken er 0420 om natten:

[...] og her er Baby med vidåpne øyne som ringblomster [...] Det er dette som bringer hat og blodsutgytelser, det er det dette gjør.

Hun forsøker å lese den franske 1600-tallsforfatteren François de la Rochefoucauld (1613-80), men finner ikke roen. I stedet kommer selvbebreidelsene:

Jeg vil aldri bli berømt [...] Jeg gjør ingenting. Absolutt ingenting. Jeg pleide å bite negler, men jeg gjør heller ikke det lenger. Jeg er ikke i stand til å skaffe nok krutt til à blåse meg selv til helvete. Jeg er blitt til et stykke vrakgods. Vrakgods til a bli kvittdet er meg fra nå av.

Men hun får summet seg, og hun har innsikt i hvordan man mister oversikten om natten. Hennes kollega F. Scott Fitzgerald (1896-1940) skrev at «klokken tre om natten har en glemt pakke samme tragiske betydning som en dødsdom» (3). Det hun kaller nulltimen (zero hour), omtaler vi gjerne som ulvetimen. Da er det meste vanskelig.

Dette er tiden når den svimeslåtte sjelen er et svimmelt anheng mellom den nye dagen og den gamle, og verken våger å konfrontere den nye eller oppsummere den gamle. Dette er tiden når alle ting, kjente og gjemte, er jern som tynger ånden; når alle veier, bereiste eller jomfruelige, løser seg opp under den snublende foten, når alt foran de anspente øynene er svart. Svart nå, alt er svart. Dette er tiden for avsky, den skrekkelige timen til det seirende mørket. For det er alltid mørkest - Var det ikke den elskelige gamle kynikeren la Rouchefou- cauld som sa at det alltid er mørkest før syndfloden?

Viddet i teksten handler blant annet om hennes oppgjør med sauer.

Man kan ikke forvente at jeg kaster alt jeg har for å begynne å telle sauer $i$ min alder. Jeg hater sauer [...] Mitt hat noermer seg en fobi [...] La dem telle seg selv, hvis de er så gale etter matematikk. La dem gjøre sine egne drittjobber. Komme her, på denne tiden av døgnet, og spørre meg om å telle dem! Og de er ikke engang ekte sauer.

Hun vurderer om hun kan telle noe annet. Sine regninger, kanskje, eller alle de tingene hun burde ha gjort. Hvorfor akkurat sauer? Kanskje denne innsovningsteknikken har sin opprinnelse fra en søvnløs hyrde? Sauetellingen forener to teknikker for selvhypnose. Den ene er å visualisere en fredfull scene. Den andre er den mantraliknende rytmiske repetisjonen. Dorothy Parker var imidlertid av dem som heller tydde til alkohol og barbiturater for å få sove.

\section{Finn Skårderud \\ finns@online.no \\ Avdeling for helse- og sosialfag \\ Høgskolen i Lillehammer \\ 2626 Lillehammer}

Oppgitte interessekonflikter: Ingen

\section{Litteratur}

1. Meade M. Dorothy Parker. What fresh hell is this? New York, NY: Penguin, 1989

2. Parker D. The little hours. The New Yorker 19.8.1933: 13-14.

3. Bishop D, Levy D. Hello midnight. An insomniac's literary bedside companion. New York, NY: Simon \& Schuster, 2001

Manuskriptet ble mottatt 2.8. 2009 og godkjent 13.8. 2009. Medisinsk redaktør Anne Gitte Hertzberg. 